\title{
Capnothorax During Laparoscopy in Trendelenburg Position: A Rare Case Study
}

\section{Capnotórax Durante Laparoscopia em Trendelenburg: Um Caso Clínico Raro}

\author{
Ana Margarida DAMAS $\otimes^{1}$, Fátima GONÇALVES ${ }^{1}$, Marisa ANTUNES ${ }^{2}$, Sónia BARATA ${ }^{3}$ \\ Acta Med Port 2020 Mar;33(3):202-203 - https://doi.org/10.20344/amp.11606
}

\begin{abstract}
Pneumothorax is an infrequent complication of laparoscopic surgery. Most cases occur during upper abdominal surgery, since a headdown position (Trendelenburg) pushes the liver and peritoneum against the diaphragm, reducing gas release. When it is due to $\mathrm{CO}_{2}$ diffusion across congenital diaphragmatic defects, it usually resolves itself spontaneously after de-insufflation of the pneumoperitoneum. Increasing positive end-expiratory pressure to counteract intra-abdominal pressure is an effective measure when a pulmonary origin is excluded. We report a case of right-sided hypertensive capnothorax due to a diaphragmatic defect, during lower abdominal surgery, which was successfully managed without the need for chest drainage. This case highlights the importance of maintaining active vigilance and a high index of suspicion for pneumothorax during laparoscopic surgery.
\end{abstract}

Keywords: Head-Down Tilt/adverse effects; Laparoscopy; Pneumothorax/etiology; Positive-Pressure Respiration

\section{RESUMO}

O pneumotórax é uma complicação pouco frequente da cirurgia laparoscópica. A maioria dos casos ocorrem em cirurgias da região abdominal superior, uma vez que a posição de Trendelenburg por empurrar o fígado e o peritoneu contra o diafragma, reduz a perda de gás. Quando a causa é a difusão de $\mathrm{CO}_{2}$ através de um defeito diafragmático congénito, habitualmente resolve espontaneamente, após a desinsuflação do pneumoperitoneu. Quando se exclui uma causa parenquimatosa pulmonar o aumento de positive end-expiratory pressure para contrabalançar a pressão intra-abdominal é uma medida eficaz. O caso clínico que apresentamos refere-se a um caso de capnotórax hipertensivo que ocorreu devido à presença de um defeito diafragmático congénito, durante uma cirurgia abdominal inferior e que foi tratado com sucesso sem recorrer ao uso de dreno torácico. Este caso salienta a importância de manter uma vigilância ativa e alto indice de suspeição para o pneumotórax durante a cirurgia laparoscópica.

Palavras-chave: Decúbito Inclinado com Rebaixamento da Cabeça/efeitos adversos; Laparoscopia; Pneumotórax/etiologia; Respiração com Pressão Positiva

\section{INTRODUCTION}

Capnothorax is defined by the presence of carbon dioxide in the pleural space, and its incidence is low. ${ }^{1,2}$ It can be caused by direct injury or by passage through congenital defects, foramina or via the subperitoneal route. The increased abdominal pressure during laparoscopy can open weak points in the diaphragm, creating a pleuroperitoneal communication. The gas present in the abdominal compartment will then move into the pleural space due to a pressure gradient, usually resulting in right-side capnothorax. Unlike the pneumothorax caused by creation of bronchopleural conduit due to barotrauma, in the event of pneumothorax caused by $\mathrm{CO}_{2}$ the use of positive end-expiratory pressure (PEEP) can be helpful. ${ }^{3,4}$ Although most cases can be managed conservatively, capnothorax can be a life-threatening situation. Anesthesiologists should be aware of this complication because successful management depends on early recognition and treatment. ${ }^{5}$

\section{CASE REPORT}

A healthy 30 -year-old female patient, diagnosed with deep endometriosis was referred for elective intraabdominal laparoscopic exploration, under general anesthesia.

She had no surgical or medical history. General balanced anesthesia induction was performed, and rocuronium was administered to facilitate tracheal intubation. After 25 minutes post-induction, the first trocart was inserted and the abdominal cavity was insufflated at a pressure of $20 \mathrm{mmHg}$. Following this, a pneumoperitoneum of $12 \mathrm{mmHg}$ was uneventfully established. The patient was then placed in Trendelenburg position for surgery. At that moment blood pressure and oxygen saturation decreased, $\mathrm{ETCO}_{2}$ increased, while airway pressure rose suddenly to unacceptable levels. Moreover, auscultation revealed absent breath sounds on the right hemithorax. Endobronchial intubation was excluded, and we assumed a diagnosis of hypertensive pneumothorax. We then shifted to manual ventilation with $100 \%$ inspired oxygen and asked surgeons to release the pneumoperitoneum. This improved hemodynamics, oxygen saturation and ventilatory mechanics. With no further clinical events, surgeons slowly increased $\mathrm{CO} 2$ insufflation up to $10 \mathrm{mmHg}$, inspected the upper abdomen and were able to visualize a diaphragmatic defect of the right hemicupule.

After laparoscopic aspiration of the capnothorax and increased PEEP, surgery was completed safely. Before

1. Department of Anaesthesiology. Hospital de Santa Maria. Centro Hospitalar Lisboa Norte. Lisboa. Portugal.

2. Anestesi Operasjons Avdelingen. Universitetssykehuset Nor-Norge. Tromsø. Norway.

3. Department of Obstetrics, Gynecology and Medicine of Reproduction. Centro Hospitalar Lisboa Norte. Lisboa. Portugal.

$\triangle$ Autor correspondente: Ana Margarida Damas. anadms@gmail.com

Recebido: 27 de novembro de 2018 - Aceite: 11 de janeiro de 2019 | Copyright $\odot$ Ordem dos Médicos 2020 
extubating, an x-ray confirmed re-expansion of the lung with minimal presence of pneumothorax. The patient was safely extubated and discharged home two days later.

\section{DISCUSSION}

Despite its rareness, pneumothorax complicates up to $2 \%$ of all laparoscopic surgeries. ${ }^{2}$ The incidence after gynecologic laparoscopy appears to be lower, $0.14 \%-0.24 \%{ }^{6}$

It can occur due to bullae rupture or passage of air during abdominal insufflation. When it results from direct injury to the diaphragm, it is usually left sided, since the liver gives protection to the right hemithorax. Right-side pneumothorax is most frequently caused by the passage of carbon dioxide through weak diaphragmatic points or congenital diaphragmatic defects. ${ }^{7}$ Risk factors include old age, abdominal insufflation with pressures above $15 \mathrm{mmHg}$ and prolonged operating time (> 200 minutes). Hirata et al hypothesized that diaphragmatic defects occur more frequently in patients with endometriosis, because they share a common embryonic development process. ${ }^{6}$

Capnothorax caused by the opening of congenital defects usually occurs in upper abdominal procedures since head-up positioning pushes the liver and omentum downward, exposing the diaphragm. In our case, it occurred in head-down position during lower abdominal surgery, which is not frequent. After laparoscopic aspiration of the capnothorax, we maintained the Trendelenburg position allowing the liver to occlude the defect.

Clinical findings included increase in the end-tidal $\mathrm{CO}_{2}$ and airway pressure, together with decrease in pulse oximetry and absent ipsilateral breath sounds. Treatment consisted of prompt deflation of the pneumoperitoneum, inspired $100 \%$ oxygen, and confirmation of proper placement of the orotracheal tube. If the increase in intrathoracic pressure is sufficient to hinder venous return and reduce ventricular filling, the patient may become hemodynamically unstable. In the case of hypertensive pneumothorax, immediate treatment is mandatory. However, if it is caused by $\mathrm{CO}_{2}$ or $\mathrm{N}_{2} \mathrm{O}$, and pulmonary trauma is excluded, the pneumothorax should resolve itself within 60 minutes, without thoracentesis. ${ }^{4}$ We chose not to insert a chest tube since our treatment was effective and allowed us to proceed with laparoscopic surgery.

\section{REFERENCES}

1. Machairiotis N, Kougioumtzi I, Dryllis G, Katsikogiannis N, Katsikogianni F, Courcoutsakis N, et al. Laparoscopy induced pneumothorax. J Thorac Dis. 2014;6:S404-6

2. Murdock CM, Wolff AJ, Van Geem T. Risk factors for hypercarbia, subcutaneous emphysema, pneumothorax, and pneumomediastinum during laparoscopy. Obstet Gynecol. 2000;95:704-9.

3. Raveendran $\mathrm{R}$, Prabu HN, Ninan S, Darmalingam S. Fast track management of pneumothorax in laparoscopic surgery. Indian J Anaesth. 2011;55:91-2.

4. Kulkarni S, Kulkarni S. Use PEEP for treating capnothorax. Indian J
It is important to distinguish a pneumothorax caused by parenchymal defect from a pneumothorax caused by carbon dioxide escaping into the pleural space. In the first case, use of PEEP can exacerbate clinical findings. In the second case, the addition of PEEP will help re-expand the collapsed lung, and if equivalent to intra-abdominal pressure, it will reduce pressure difference and gas passage into the chest. In our case, releasing the pneumoperitoneum improved hemodynamic and ventilatory status, while breath sounds returned to the right hemithorax, which was suggestive of the absence of parenchymal origin.

\section{CONCLUSION}

In summary, capnothorax is rare but a potentially serious complication of laparoscopic surgery. Active monitoring is crucial since a high index of suspicion is needed to diagnose it. Treatment must be immediate if hemodynamic instability persists. Chest decompression is not mandatory however, since it usually resolves itself after releasing the pneumoperitoneum, with PEEP being a helpful measure to re-expand the lung and reduce air leak.

\section{PROTECTION OF HUMANS AND ANIMALS}

The authors declare that the procedures were followed according to the regulations established by the Clinical Research and Ethics Committee and to the Helsinki Declaration of the World Medical Association.

\section{DATA CONFIDENTIALITY}

The authors declare having followed the protocols in use at their working center regarding patients' data publication.

\section{INFORMED CONSENT}

Obtained.

\section{CONFLICTS OF INTEREST}

All authors report no conflict of interest.

\section{FUNDING SOURCES}

The authors declare that there were no external sources of study for the performance of this article.

\section{Anaesth. 2011;55:550-2.}

5. Voyles CR, Madden B. The "floppy diaphragm" sign with laparoscopicassociated pneumothorax. JSLS. 1998;2:71-3.

6. Hirata T, Nakazawa A, Fukuda S, Hirota Y. Four cases of postoperative pneumothorax among 2814 consecutive laparoscopic gynecologic surgeries: a possible correlation between postoperative pneumothorax and endometriosis. J Minim Invasive Gynecol. 2015;22:980-4.

7. Ghodki PS, Thombre SK. Capnothorax during laparoscopic fundoaplication: diagnosis and anesthetic management. J Acad Med Sci. 2012;2:118-20 